\title{
Prevalence of Indigestion in Buffaloes in and around Pantnagar Region of Uttarakhand, India
}

\author{
Richa Arora ${ }^{1}$, Arpit Tyagi ${ }^{2}$, S. Shekhar ${ }^{3}$, V.S. Rajora ${ }^{2}$ and Niddhi Arora ${ }^{2}$ \\ ${ }^{1}$ Department of Animal Biotechnology, IVRI, Izatnagar, Bareilly, U.P. India \\ ${ }^{2}$ Department of Veterinary Medicine, CVASc., GBPUAT,, Pantnagar, U.K., India \\ ${ }^{3}$ Veterinary Science, Krishi Vigyan Kendra (ICAR-NRRI), Koderma, Jharkhand \\ *Corresponding author
}

\section{A B S T R A C T}

\section{Keywords \\ Indigestion, Buffaloes, Gastro- intestinal disorders, Acid indigestion \\ Article Info \\ Accepted: \\ 26 June 2018 \\ Available Online: \\ 10 July 2018}

The present study was conducted in the Department of Veterinary Medicine, Teaching Veterinary Clinical Complex and Instructional Dairy Farm (IDF), C.V.A.Sc., GBPUA\&T, Pantnagar, U.S. Nagar (Uttarakhand). A total of 608 buffaloes presented for the treatment at TVCC of the college and IDF of the university were screened for indigestion and included in the prevalence study. Out of 608 bubaline cases screened, $169(27.80 \%)$ were found to be suffering from gastro-intestinal disorders while number of buffaloes suffering from indigestion were $63(10.36 \%)$ of the total number of cases screened. Of these maximum prevalence was recorded for simple indigestion $34(53.97 \%)$ followed by acid indigestion $16(25.40 \%)$ and alkaline indigestion 13 $(20.63 \%)$.

\section{Introduction}

Buffalo, a triple purpose animal, provides milk, meat and mechanical power to mankind. Due to its highly nutritious milk, leaner meat and best draught power for wet environments buffalo offers immense potential for the improvement of livelihood. Buffalo can efficiently convert low quality feed stuffs like straws and agro-industrial waste into human food, improve soil structure through biofertilizer and a financial asset which can be sold when needs arise. Although, buffalo is the flagship of all agricultural revolutions; green, white and red but unfortunately has been neglected in the past (Pasha and Hayat, 2012).

Rumen disorders are of a greater clinical interest as they affect large number of animals and incur great losses in both production and cost of treatment of the affected ruminants (Ratib, 2001). The most common ruminal disorders such as tympany, indigestion and impaction are characterized by poor appetite, altered $\mathrm{pH}$, reduced rumen motility and decreased microbial counts (Radostits et al., 2006). Sudden change in the feed is the most common cause of indigestion in ruminants. Other factors such as feeding spoiled and 
moulded feeds, use of antibiotics especially via oral route, sudden changes in climatic conditions also cause indigestion (Radostits et al., 2006). Due to abrupt changes in feed, the ruminal microflora is unable to adapt resulting in indigestion. As rumen microflora plays an important role in ruminant digestion (Yokoyama and Johnson, 1998), ruminal dysfunction leads to reduced rumen protozoal and bacterial count makes animal susceptible to various metabolic diseases and digestive disorders like simple indigestion, acidic indigestion, alkaline indigestion or post parturient indigestion. Mild simple indigestion is self-limiting in nature and the $\mathrm{pH}$ of rumen liquor tends towards mild acidosis or mild alkalosis. Reduced appetite is one the early clinical signs seen in case of indigestion (Radostits et al., 2006) while subsequent prominent symptoms include anorexia, depression, reduced or complete cessation of rumination and eructation, decreased reticuloruminal movements and significant reduction in bacterial and protozoal counts (Irmak et al., 1998). Indigestion also leads to hepatic disturbances (Padmaja and Rao, 2012), increase occurrences of leucocytosis (Stocker et al., 1999) and decrease milk yield in affected animals (Singh et al., 1996). The ultimate result of these clinical conditions is production and economic losses to the farmers. With the climate change and global warming ruminants are more likely to suffer from ruminal disorders as the fluctuation in temperature and humidity exerts great effects on animal physiology, performance and production as well as the ruminal bacterial diversity; which altered significantly in response to raised temperature (Tajima et al., 2007).

\section{Materials and Methods}

The present study was conducted in the Department of Veterinary Medicine, Teaching Veterinary Clinical Complex and Instructional Dairy Farm (IDF), C.V.A.Sc., GBPUA\&T,
Pantnagar, U.S. Nagar (Uttarakhand). A total of 608 buffaloes presented for the treatment at TVCC of the college and IDF of the university were screened for indigestion and included in the prevalence study. All the buffaloes were put through preliminary screening for the presence of gastro-intestinal disorders. It consisted of history taking, clinical manifestations, recording of temperature, pulse and respiratory rate. Buffaloes found to have manifestations simulating the indigestion like in appetance or anorexia, slow or suspended rumination, constipation and diarrhoea, palpation of left paralumbar fossa showing doughy condition, signs of dehydration, sunken eyes, rough hair, fissured muzzle and sudden drop in milk yield were included in the epidemiological study. After preliminary screening of buffaloes for indigestion, prevalence of different types of indigestion viz. simple indigestion, acid indigestion and alkaline indigestion were recorded.

\section{Results and Discussion}

Out of 608 buffalo patients 169 i.e. $27.80 \%$ of the cases were found to be suffering from gastro-intestinal disorders while number of buffaloes suffering from indigestion were 63, which is $10.36 \%$ of the total number of cases screened, as shown in Table 1.

The prevalence for digestive disorders was found to be lower than that found by Pallab et al., (2012) and Badruzzaman et al., (2015), who reported prevalence of digestive disorders to be $47.05 \%$ and $45.14 \%$ in cattle respectively.

During this study out of 63 buffaloes suffering from indigestion, simple indigestion was found to be the most common form of indigestion with 34 buffaloes (53.97\%) followed by acid indigestion in $23.40 \%$ of the cases and alkaline indigestion with $20.63 \%$ of the total cases, as shown in Table 2 and Fig. 1. 
Table.1 Prevalence of gastro-intestinal disorders and indigestion in buffaloes

\begin{tabular}{|l|l|l|}
\hline $\begin{array}{l}\text { Total number of buffaloes } \\
\text { patients observed }\end{array}$ & $\begin{array}{l}\text { Number of buffaloes suffering } \\
\text { from gastro-intestinal disorders }\end{array}$ & $\begin{array}{l}\text { Number of buffaloes suffering } \\
\text { from indigestion }\end{array}$ \\
\hline $\mathbf{6 0 8}$ & $169(27.80 \%)$ & $63(10.36 \%)$ \\
\hline
\end{tabular}

Table.2 Prevalence of indigestion in buffaloes

\begin{tabular}{|l|l|}
\hline Type of indigestion & Number of buffalo patients \\
\hline Simple indigestion & $34(53.97 \%)$ \\
\hline Acid indigestion & $16(25.40 \%)$ \\
\hline Alkaline indigestion & $13(20.63 \%)$ \\
\hline Total & $\mathbf{6 3}(\mathbf{1 0 0 \%})$ \\
\hline
\end{tabular}

Fig.1 Prevalence of indigestion in buffaloes

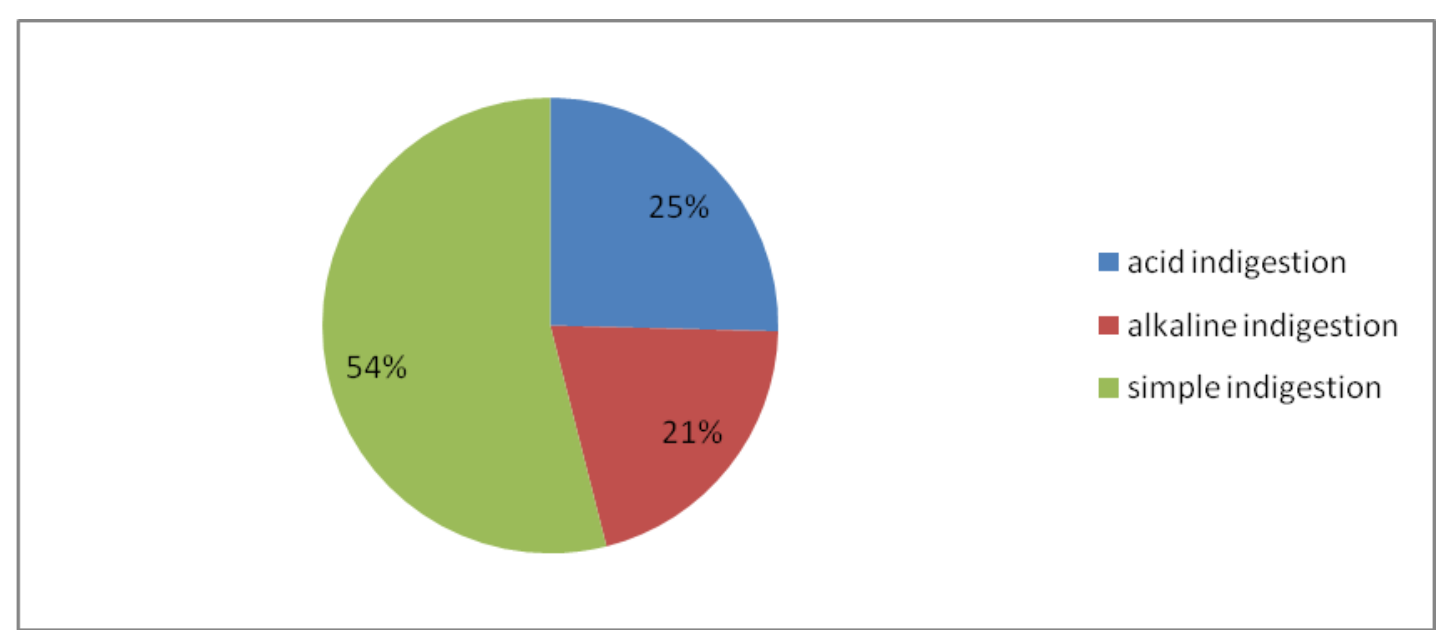

The results were in similar trend to those reported by Philip and Al-Badrani (2008) and Shah et al., (2013), who have reported that simple indigestion was most common followed by acid indigestion and alkaline indigestion in cattle and sheep respectively.

In conclusion, rumen disorders are of a greater clinical interest as they affect large number of animals and incur great losses in both production and cost of treatment of the affected ruminants. A total of 608 bubaline cases were recorded at Veterinary Teaching Hospital (VTH) Pantnagar and Instructional Dairy Farm (IDF), Nagla. Out of 608 bubaline cases screened, $169(27.80 \%)$ were found to be suffering from gastro-intestinal disorders while number of buffaloes suffering from indigestion were $63(10.36 \%)$ of the total number of cases screened. Of these maximum prevalence was recorded for simple indigestion $34(53.97 \%)$ followed by acid indigestion $16 \quad(25.40 \%)$ and alkaline indigestion 13 (20.63\%).

\section{Acknowledgement}

The authors are thankful to Dean, College of Veterinary and Animal Sciences, Pantnagar and Joint Director, IDF, Pantnagar for 
providing the necessary facilities and help to carry out the investigation.

\section{References}

Badruzzaman ATM, Siddiqui MSI, Faruk MO, Lucky NS, Zinnah MA, Hossain FMA, Rahman MM. Prevalence of infectious and non-infectious diseases in cattle in Chittagong district of Bangladesh. Int. J. Biol. Res. 2015; 3(1): 1-4.

Irmak K, Sen I, Mahmut OK, Turgut K. Effect of simple indigestion and pneumonia on plasma thiamine concentration in cattle. Kafkas Univ. Vet. Fak. Derg. 1998; 4: 63-67.

Padmaja K, Rao DST. Biochemical and therapeutic studies on postparturient indigestion (ppi) with particular reference to hepatic insufficiency in buffaloes. Int. J. of Pharma. and Bio. Sci. 2012; 3: 40-45.

Pallab MS, Ullah SM, Uddin MM, Miazi OF. A cross sectional study of several diseases in cattle at Chandanaish Upazilla of Chittagong district, Bangladesh. Scientific J. of Vet. Adv.2012; 1(1): 28-32

Pasha TN, Hayat Z. Present situation and future perspective of buffalo production in Asia. The J. of Ani. and Plant Sci. 2012; 22(3): 250-256.

Philip KA, Al-Badrani BA. Changed in the ruminal contents of buffaloes suffering from digestive disorders. Iraqi. J. of Vet. Sci. 2008; 151-163.

Radostits OM, Gay CC, Hinchcliff KW and Constable. PD Ed., Veterinary
Medicine: A textbook of cattle, horses, sheep, pigs and goats, 10th Edition, Saunders Publishers; 2006.

Ratib MH. Correlation between some ruminal contents and the respective morphological changes in sheep in Assiut governorate. M.V.Sc. Fac. of Vet. Medicine, Assiut. University, 2001.

Shah OS, Bhat RA, Shaheen MS, Muhee A. Studies on prevalence and haematobiochemical changes in different rumen dysfunction in sheep with special reference to prebiotic and probiotic therapy in simple indigestion. $2^{\text {nd }}$ Int. Conf. Egyptian Society of Biological Science. 2013; 56-57.

Singh N, Akbar MA, Kumari R and Khanna BM. Effect of some treatment on ruminal environment and milk production in clinical cases of indigestion in buffaloes. Ind. Vet. Med. J., 1996; 20: 115-118.

Stocker H, Lutz H, Rusch P. Clinical, haematological and biochemical findings in milk-fed calves with chronic indigestion. Vet. Rec.1999; 145: 307-311.

Tajima K, Nonaka I, Higuchi K, Takusari N, Kurihara M, Takenaka A, Aminov R. Influence of high temperature and humidity on rumen bacterial diversity in Holstein heifers. Anaerobe, 2007; 13(2): 57-64.

Yokoyama MT, Johnson KA. The ruminant animal: Digestive physiology and nutrition, D.C. Church ed. Prentice Hall. 1998; 125.

\section{How to cite this article:}

Richa Arora, Arpit Tyagi, S. Shekhar, V.S. Rajora and Niddhi Arora. 2018. Prevalence of Indigestion in Buffaloes in and around Pantnagar Region of Uttarakhand, India. Int.J.Curr.Microbiol.App.Sci. 7(07): 3765-3768. doi: https://doi.org/10.20546/ijcmas.2018.707.436 